https://doi.org/10.30910/turkjans.679913

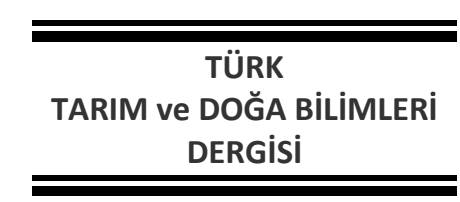

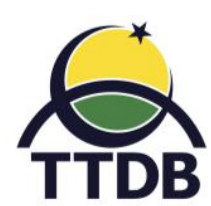

www.dergipark.gov.tr/turkjans

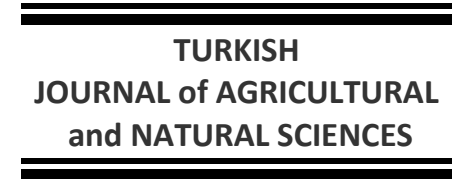

Araştırma Makalesi

\title{
Yarı Kurak İklim Koşullarında Farklı Anaçlar Üzerinde Yetiştirilen Sofralık Üzüm Çeşitlerinin Bazı Çekirdek Özellikleri ile Yağ Asidi Kompozisyonlarının Belirlenmesi ${ }^{\S}$
}

\author{
M. IIIhan ODABAŞIOĞLU*, Sadettin GÜRSÖZ
}

Harran Üniversitesi, Ziraat Fakültesi, Bahçe Bitkileri Bölümü, Şanlıurfa

*Sorumlu yazar: milhanodabasioglu@harran.edu.tr \section{Get}

Geliş Tarihi: 02.10.2019

Düzeltme Geliş Tarihi: 18.11.2019

Kabul Tarihi: 18.11.2019

Üzüm çekirdeklerinin kayda değer bir yağ içeriğine sahip olduğu uzun yıllardır bilinmesine karşın; üzüm çekirdeği yağının ticari olarak üretimi ancak son yıllarda yaygınlaşmıştır. Farklı üzüm çeşitlerinin yağ asitleri kompozisyonlarının ve çekirdek özelliklerinin incelendiği çalışmalar literatürde yaygın olmasına karşın; bağda kullanılan anacın bunlar üzerine etkilerinin ortaya konduğu araştırmalar kısıtlıdır. Bu çalışmada; farklı anaçlar (1103 P ve 110 R) üzerine aşılanmış sofralık üzüm çeşitlerinin (Red Globe, Trakya İlkeren, Ata Sarısı, Hatun Parmağı ve Horoz Karası) bazı çekirdek özellikleri ile yağ asitleri kompozisyonları incelenmiştir. Bağda kullanılan anacın; 1 kg'daki çekirdek sayısı, çekirdek nemi ve protein miktarı üzerinde etkili olduğu ancak çekirdek boyutları, sabit yağ içeriği, kül miktarı ve 100 çekirdek ağırlığını değiştirmediği belirlenmiştir. Bu özelliklerin genellikle çeşide bağlı olarak değiştiği saptanmıştır. Bununla birlikte en yüksek sabit yağ içeriği 1103 P anacına aşılı Ata Sarısı üzüm çeşidinde (\%16.30 w/w) tespit edilmiştir. Incelenen tüm çeşitlerde en yüksek miktarda bulunan yağ asidinin Linoleik asit (C18:2n-6) olduğu ve bunu sırasıyla Oleik (C18:1), Palmitik (C16:0), Stearik (C18:0) ve Bütirik (C4:0) asitlerin izlediği belirlenmiştir. En yüksek Linoleik asit içeriği (\%67.97) 1103 P anacına aşılı Trakya İlkeren üzüm çeşidinde saptanmıştır. Bu araştırmada çeşitlerin yağ asitleri üzerinde mutlak bir etkisinin olduğu, bununla birlikte anaçların yağ asitlerini sınırlı düzeyde etkilediği ortaya çıkarılmıştır.

Anahtar kelimeler: Üzüm çekirdeği, yağ asitleri, üzüm çeşitleri, asma anaçları.

\section{Determination of Some Seed Properties and Fatty Acid Composition of Table Grape Genotypes Grown on Different Rootstocks in Semi-Arid Climate Conditions}

\begin{abstract}
Although it has been known for a long time that grape seeds have a significant oil content, commercial production of grape seed oil has only become widespread in recent years. Although, the studies examining the fatty acid compositions and characteristics of seeds on different grape varieties are common in the literature; research on the effects of rootstock used in the vineyard on them is limited. In this study; some seed characteristics and fatty acid compositions of table grape varieties (Red Globe, Trakya Ilkeren, Ata Sarısı, Hatun Parmağı, Horoz Karası) grafted on different rootstocks (1103 P and $110 \mathrm{R}$ ) were investigated. It was found that the number of seeds per $1 \mathrm{~kg}$, seed moisture and protein content of seeds was vary by the rootstock, but seed sizes, total oil content, ash amount and seed weight not affected by them. However, it was revealed that these characteristics generally vary depending on the grape genotype. In addition, the highest oil content was found in Ata Sarısı (16.30\% w/w) which grafted onto 1103 P rootstock. Linoleic acid (C18: $2 n-6)$ was found to be the highest amount of fatty acid in all cultivars and it was respectively followed by Oleic (C18:1), Palmitic (C16:0), Stearic (C18:0) and Butyric (C4:0) acids. The highest Linoleic acid content (67.97\%) was found in Trakya Illkeren variety grafted onto $1103 \mathrm{P}$ rootstock. Also, it was revealed that rootstocks had a limited effect on fatty acid compositions of grape seeds but varieties had an absolute effect on them.
\end{abstract}

Key words: Grape seed, fatty acids, grape varieties, grape rootstocks. 


\section{Giriş}

Dünyada önemli bitkisel üretim kollarından biri bağcılıktır. 2017 verilerine göre dünyada toplam 6931353 ha alanda yıllık 74276583 ton üzüm üretilmektedir (FAO, 2019). Bu üretimin önemli bir bölümü (\%52) şarap endüstrisinde ham madde olarak kullanılmaktadır (Göktürk Baydar ve Akkurt, 2001; Akın ve Altındişli, 2010; Bashimov, 2017; OIV, 2019). Nitekim dünyada yıllık 249804000 hL şarap üretiminin yapılıyor olması bu verileri desteklemektedir. Türkiye ise üzüm üreten ülkeler arasında üretim miktarı bakımından 6. sırada yer almaktadır. 2017 yılında yaklaşık 416907 ha alanda yıllık 4.2 milyon ton üzüm üretimi gerçekleştirilen Türkiye'de; toplam üzüm üretiminin \% 12'sini şaraplık üzüm çeşitleri oluşturmaktadır. Üzüm üretiminin kalan bölümü ise sofralık (\%50) ve kurutmalık (\%38) üzüm çeşitlerinden oluşmaktadır (TüiK, 2019). OIV (2019) verilerine göre ise Türkiye'de toplam üzüm üretiminin sadece \%2'si şarap yapımında kullanılmaktadır. Bu bilgiler ışığında ülkemizde üretilen üzümlerin yaklaşık \%10'luk bir kısmının şıralık olarak farklı yöresel ürünlerin yapımında kullanıldığı söylenebilir. Nitekim araştırmacılar bu oranın yıllara ve üzüm şırasından elde edilen gıda ürünlerine olan talebe bağlı olarak değişmekle birlikte \%10-40 arasında seyredebildiğini aktarmışlardır (Gök Tangolar ve ark., 2009; Akın ve Altındişli, 2010; Çelik ve ark., 2010; Sabır ve ark., 2012).

Dünya genelinin aksine, ülkemizde şaraplık ve şıralık üzüm çeşitlerinin üretim oranı sofralık ve kurutmalık üzüm çeşitlerine kıyasla çok daha az gerçekleşmesine rağmen önemli miktarlarda cibre atık olarak ortaya çıkmaktadır (Bekar, 2016). Ağırlık olarak; yaş üzüm tanesinin yaklaşık \%2 - 6'sını (Mironeasa ve ark., 2010; Sabır ve ark., 2012; Fernandes ve ark., 2013; Kamiloğlu ve Üstün, 2014) ve yaş üzüm salkımının ise yaklaşık \%1-4'ünü (Mironeasa ve ark., 2010; Fernandes ve ark., 2013) çekirdeklerin oluşturduğuna ilişkin önceki çalışmalar dikkate alındığında, 2017 yılı itibariyle ülkemizde minimum 4880 ton, maksimum 29280 ton üzüm çekirdeğinin; gerek şarap endüstrisinin gerekse üzüm şırasından diğer gıda mamullerini üreten endüstri kollarının atığı olarak ortaya çıktığı düşünülmektedir. Nitekim üst sınır olarak belirttiğimiz miktar Gök Tangolar ve ark. (2009) tarafından belirtilen değerle paralellik göstermektedir. Bu denli yüksek miktarlarda ve her yıl ortaya çıkan üzüm çekirdeğinin endüstriye ve ekonomiye yeniden kazandırılması son derece önemlidir.

Son yıllarda gıda endüstrisinde farklı bitkisel ürünlerin yağları üzerine yapılan araştırmalar artmış ve alternatif bitkisel yağlar daha detaylı olarak incelenmeye başlamıştır. Üzüm çekirdeği; içeriğinde bulunan \%3.91-24.76 yağ içeriği ile gerek araştırmacıların gerekse gıda sanayiinin dikkatini çeken bitkisel kökenli yağ kaynaklarından biridir (Yoo ve ark., 1984; Lachman ve ark., 2015). Bununla birlikte doymamış yağ asitlerince zengin olması, üzüm çekirdeği yağını diğer bitkisel yağlar içerisinde öne çıkarmaktadır (Garavaglia ve ark., 2016). Özellikle oleik (\%9.97-31.20) ve linoleik (\%49.080.5) asitlerce zengin yapısı üzüm çekirdeği yağına olan ilginin temel sebeplerindendir (Ohnishi ve ark., 1990; El-Shami ve ark., 1992; Sabır ve ark., 2012; Lachman ve ark., 2015). Bununla birlikte toplam doymuş ve doymamış yağ asitlerinin içeriği; pek çok araştırmacının sağlık kaynağı olarak ifade ettikleri zeytin yağına yakın seviyelerde seyretmektedir (Stefanoudaki ve ark., 1999; Kamal-Eldin ve Andersson, 1997). Nitekim araştırmacılar kolesterol kaynaklı oluşan yüksek tansiyonun düşürülmesinde üzüm çekirdeği tüketiminin olumlu etkilerinin olduğunu bildirmektedirler (Sivaprakasapillai ve ark., 2009; Asadi ve ark., 2010).

Günümüz endüstri kolları arasında üzüm çekirdeği yağının kullanımı en çok kozmetik, ilaç ve gıda sanayilerinde yoğunlaşmıştır (Gök Tangolar ve ark., 2009). Üzümün son yüzyılda yeniden keşfedilen iyileştirici ve sağlığı koruyucu özellikleri eski çağlarda da bilinmekte ve kullanılmaktaydı. Ayurvedik tedavide kullanımının devam etmesi bunun en güzel örneklerinden biridir (Singh ve ark., 2015). Son yıllarda, üzüm çekirdeğinden elde edilen extraktların; canlılardaki oksidatif stresin olumsuz etkilerinin azaltılmasında, merkezi sinir sisteminin kuvvetlendirilmesinde ve DNA yapısında oluşan hasarların onarılmasında olumlu etkilerinin saptanması, çekirdekli üzüm çeşitlerine olan ilgiyi canlı tutmaktadır (Balu ve ark., 2005; Balu ve ark., 2006; Feng ve ark., 2007; Matthaus, 2008; Çetin, 2010).

Üzüm çekirdeklerinden elde edilen yağ miktarı üzüm çeşidine göre değişim göstermektedir. Ayrıca üzüm çekirdeklerinin protein içerikleri \%6.5316.71 arasında değişmekle birlikte farklı çeşitlerin farklı protein içeriğine sahip olduğu da önceki çalışmalarda ortaya konulmuştur (Gök Tangolar ve ark., 2009; Santos ve ark., 2011). Nitekim üzüm çekirdeği katkılı yemlerin kullanımının hayvan beslemede hayvan canlı ağırlığını, yumurta tavukçuluğunda ise yumurta ağırlığını arttırması; üzüm çekirdeğinin önemli bir protein kaynağı olduğunu göstermektedir (Trushenski ve ark., 2009; Hajati ve ark., 2015; Kara ve ark., 2016).

İnsan sağlığında doğrudan ve dolaylı olarak, ayrıca hayvan beslemede yem katkısı olarak göz ardı edilemeyecek olumlu etkilere sahip olan üzüm çekirdeğinin yağ asitleri profili ile toplam yă̆ 
içeriğinin çeşitli çevresel ve içsel etkenlere bağlı olarak değişim gösterdiği bilinmektedir. Nitekim önceki araştırmalarda; genotipin (Yoo ve ark., 1984; Ohnishi ve ark., 1990; Göktürk Baydar ve Akkurt, 2001; Beveridge ve ark., 2005; Göktürk Baydar ve ark., 2007; Rababah ve ark., 2008; Pardo ve ark., 2009; Gök Tangolar ve ark., 2009; Yi ve ark., 2009; Akın ve Altındişli, 2010; Santos ve ark., 2011; Sabır ve ark., 2012; Fernandes ve ark., 2013; Demirtaş ve ark., 2013; Lachman ve ark., 2015); yetiştiricilik yapılan yörenin ekolojik özelliklerinin (Crews ve ark., 2006; Mironeasa ve ark., 2010), tane olgunlaşmasının farklı dönemlerinin (Rubio ve ark., 2009), hasat sonrası üzümlere- çekirdeklere uygulanan farklı kurutma tekniklerinin (Oomah ve ark., 1998; Özkaya ve ark., 2014), çekirdeklerin temin edildiği ya da saklandığı koşulların (Mironeasa ve ark., 2010) ve yağ ekstraksiyon yönteminin (Rabak, 1921; Yoo ve ark., 1984; Beveridge ve ark., 2005) toplam yağ ve yağ asitleri kompozisyonunu değiştirebileceği bildirilmiştir. Bununla birlikte çekirdeklerin nem, protein ve kül içeriklerinin de benzer etkenlere bağlı olarak değişebileceği farklı araştırmacılar tarafından ortaya konulmuştur (Yoo ve ark., 1984; Oomah ve ark., 1998; Rababah ve ark., 2008; Yi ve ark., 2009; Gök Tangolar ve ark., 2009; Rubio ve ark., 2009; Mironeasa ve ark., 2010; Santos ve ark., 2011). Ancak farklı anaçlar üzerine aşılı üzüm çeşitlerinin çekirdeklerindeki sabit yağ içeriği, yağ asitlerinin kompozisyonu ve protein içeriği vb. çekirdek özelliklerine ilişkin araştırmalar oldukça sınırlı düzeydedir.

Bu çalışmada, iki farklı Amerikan asma anacı (1103 P ve $110 R$ ) üzerine aşılı 5 farklı sofralık üzüm çeşidinden elde edilen üzüm çekirdeklerinin bazı pomolojik özellikleri ile sabit yağ içerikleri, yağ asitleri kompozisyonları ve protein içerikleri incelenmiştir. Asma anaçlarının; üzerlerine aşılı olan çeşitlerin çekirdek özelliklerine ve çekirdeklerin yağ asidi kompozisyonlarına etkileri tespit edilmeye çalışılmıştır.

\section{Materyal ve Yöntem Deneme alanı}

Çalışma, Harran Üniversitesi Ar-Ge bağında çift kollu kordon terbiye şekli verilmiş omcalardan üzüm hasadı döneminde çıkarılmış çekirdeklerde yürütülmüştür. Omcalar 1,5 m. x $3 \mathrm{~m}$. sıra üzeri ve sıra arası mesafelerde yetiştirilmiş olup, çeşitler 3 yaşında iken örnekler alınmıştır. Araştırmanın yürütüldüğü 2018 yılında bağda sulama yapılmamıştır.

\section{Deneme alanının iklim verileri}

Deneme alanının yağış ve sıcaklık verileri Şekil 1'de sunulmuştur.

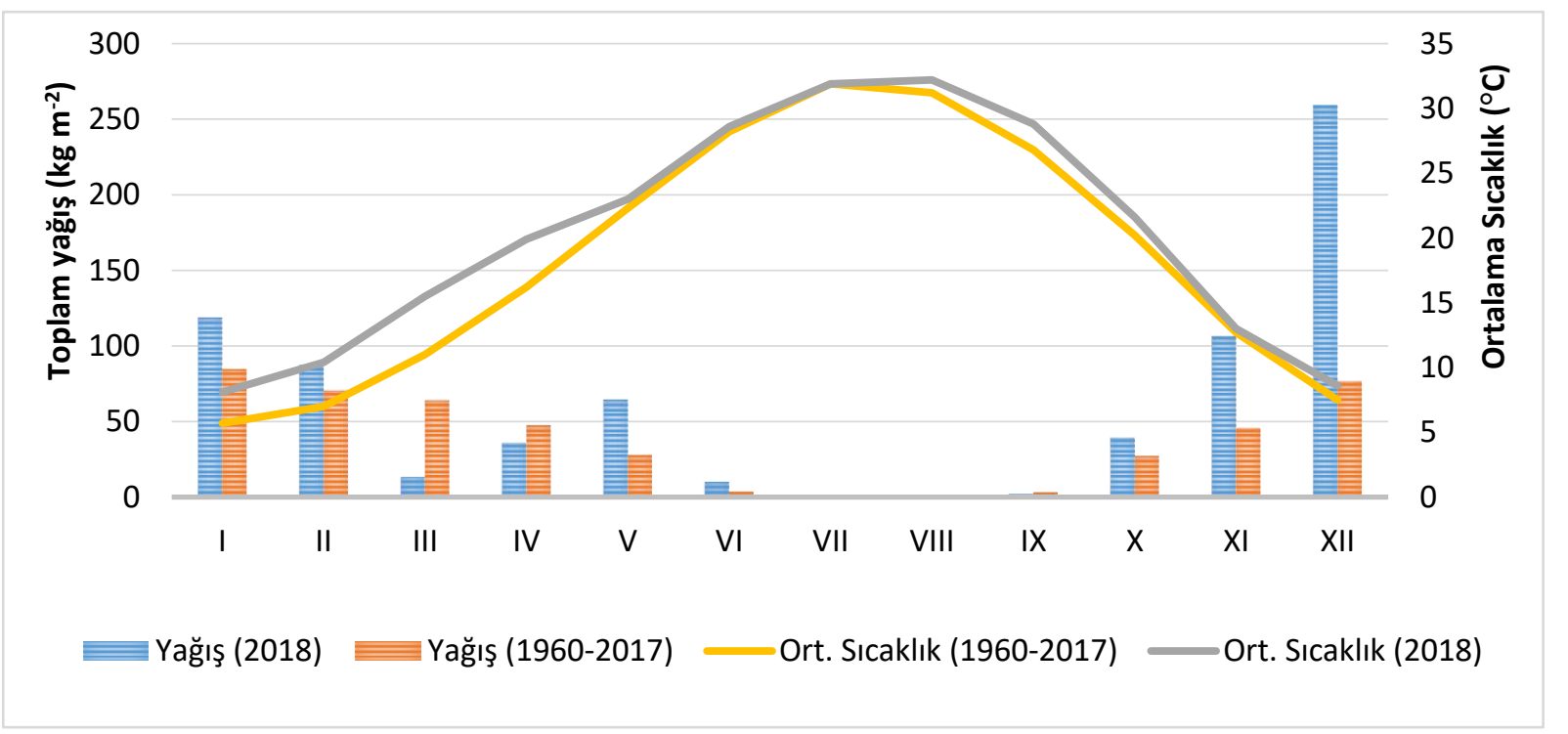

Şekil 1. Araştırmanın yürütüldüğü bağın toplam yağış ve ortalama sıcaklık değerleri.

\section{Materyal}

Araştırmada iki farklı Amerikan asma anacı (1103 P ve 110 R) üzerine aşılanmış sofralık üzüm çeşitlerinin çekirdekleri incelenmiştir. Incelenen çeşitler; Red Globe, Trakya IIlkeren, Ata Sarısı, Hatun Parmağı ve Horoz Karası üzüm çeşitleridir. Çeşitlere ait çekirdekler her çeşidin hasat olgunluğuna ulaştığı tarihte çıkarılmıştır. Üzümlerden çıkarılan çekirdekler, üzerlerinde pulp ve şıra artıkları kalmaması için saf suda yıkanmış ve havlu kâğıt yardımıyla kurulandıktan sonra oda şartlarında (+24 $\left.{ }^{\circ} \mathrm{C}\right)$ gölgede 3 gün süreyle karıştırılarak kurutulmuştur. Kurutma işlemi tamamlandıktan sonra çekirdekler analizler yapılana kadar cam desikatörde muhafaza edilmiştir. 


\section{Yöntemler \\ 100 çekirdek ağırlığı}

Her anaç-çeşit kombinasyonuna ait çekirdekler 4 tekerrürlü olarak ayrılmıştır. Her tekerrürde tesadüfi olarak seçilmiş 100'er adet çekirdek yer almıştır. Gruplandırılmış olan çekirdekler daha sonra $0.01 \mathrm{~g}$ hassasiyetle ölçüm yapan hassas terazide tartılmıştır (Uslu ve Dardeniz, 2009).

\section{1 kg çekirdek sayısı}

Tesadüfi olarak anaç-çeşit kombinasyonlarından 4 tekerrürlü olarak alınan 20 g'lık çekirdekler el ile sayılıp kaydedilmiştir. Daha sonra elde edilen çekirdek sayısı 50 ile çarpılarak 1 kg'daki çekirdek sayısı elde edilmiştir.

\section{Çekirdek nemi}

Her anaç-çeşit kombinasyonuna ait çekirdeklerden 3 tekerrürlü olmak üzere alınan çekirdek örneklerinin nemleri KERN marka DBS 60-3 model tohum nem tayini cihazında tespit edilmiştir.

\section{Çekirdek eni ve boyu}

Anaç-çeşit kombinasyonlarına ait çekirdekler, her tekerrürde 30'ar adet olmak üzere 4 tekerrürlü olarak ayrılmış ve $0.001 \mathrm{~mm}$ hassasiyette ölçüm yapan dijital kumpas yardımıyla en-boy ölçümleri yapılmıştır. Çekirdek eni ölçümleri, çekirdeklerin en geniş iki noktası arasında yapılmıştır. Çekirdek boyu ölçümleri ise çekirdeklerin en uzun iki noktası arasında yapıımıştır (Ağaoğlu, 1999; Uslu ve Dardeniz, 2009; Mironeasa ve ark., 2010) (Şekil 1).

\section{Sabit yağ tayini}

Etüvde $65{ }^{\circ} \mathrm{C}^{\prime}$ de 72 saat kurutulmuş olan çekirdeklerden, her tekerrürde $10 \mathrm{~g}$ çekirdek yer alacak şekilde 3 tekerrürlü olarak çekirdekler ayrılmıştır. Çekirdekler kahve değirmeninde öğütülmüş, öğütülen çekirdekler Soxhlet cihazında 6 saat süre ile sıvı hekzanla yağ ekstraksiyonuna tabi tutulmuştur (Göktürk Baydar ve ark., 2007; Akın ve Altındişli, 2010; Sabır ve ark., 2012; Canbay ve Bardakçı, 2011). Ekstraksiyon sonlandırıldıktan sonra balon jojelerde biriken yağ-hekzan karışımından hekzanın ayrılması için balon jojeler etüvde $60^{\circ} \mathrm{C}^{\prime}$ de 24 saat bekletilmiştir. Sabit yağ miktarı ağırlık yüzdesi (\%w/w) olarak saptanmıştır (Lachman ve ark., 2015).

\section{Yağ asitleri tayini}

Daha önce Soxhlet cihazında ektraksiyonu yapılan yağlar ışık geçirmez vida kapaklı tüplerde +4 ${ }^{\circ} C^{\prime}$ de yağ asitlerinin tayini yapılana kadar muhafaza edilmiştir. Türevlendirme işlemi Slover ve Lanza (1979)'a göre yapılmıştır (Akın ve Altındişli, 2010).
Yağ asitleri tayini Shimadzu Nexis GC-2030 marka gaz kromatografisi-külte spektrometresinde yapılmıştır. FID dedektör ve TR-CN100 (100m x $0,25 \mathrm{~mm} \times 0,20 \mathrm{um})$ kolon kullanılmıştır. $1 \mu \mathrm{L}$ enjeksiyon hacmi ve $1 \mathrm{ml} \mathrm{dk}^{-1}$ '। $ı$ akış hızında, $240{ }^{\circ} \mathrm{C}$ dedektör sıcaklığında okumalar yapılmıştır. Taşıyıcı gaz olarak Hidrojen kullanılmıştır. Yağ asitleri tayini 3 tekerrürlü olarak yapılmıştır.

\section{Protein tayini}

Etüvde $65^{\circ} \mathrm{C}^{\prime}$ de 72 saat kurutulmuş olan üzüm çekirdekleri kahve değirmeninde toz haline gelene kadar öğütülmüş daha sonra toz haline getirilmiş olan çekirdek örnekleri; 3 tekerrürlü olarak, her tekerrürde $0.5 \mathrm{~g}$ örnek yer alacak şekilde yaş yakma yöntemiyle yakılmıştır. Khejdal metoduyla \% $\mathrm{N}$ miktarı tespit edilmiştir. Elde edilen $\% \mathrm{~N}$ değeri 6.25 katsayısı ile çarpılarak toplam protein miktarı tespit edilmiştir (Kaçar, 1972; Mironeasa ve ark., 2010).

\section{Endosperm gelişimini tamamlamış çekirdek oranı}

Endosperm gelişimini tamamlamış çekirdek oranının belirlenmesinde Ağaoğlu (2002)'nun bildirdiği yüzdürme metodu kullanılmıştır. Çalışmada incelenen anaç-çeşit kombinasyonlarına ait çekirdekler 3 tekerrürlü olarak her tekerrürde rastgele alınmış 50 çekirdek yer alacak şekilde ayrılmıştır. $50 \mathrm{ml}$ hacimli Falkon tüplerine saf su eklenmiş ve çekirdekler Falkon tüplerine bırakılmıştır. $5 \mathrm{dk}$ beklenmiş ve dibe çöken çekirdekler sayılmıştır. Dibe çöken çekirdeklerin, tüplere konan toplam çekirdeklere oranı (\%) saptanmıştır.

\section{Kül miktarı}

Anaç-çeşit kombinasyonlarına ait çekirdekler 3 tekerrürlü olarak ve her tekerrürde $0,5 \mathrm{~g}$ örnek yer alacak şekilde porselen krozelere aktarılmıştır. Krozelere aktarılan örnekler önce $+200{ }^{\circ} \mathrm{C}$ 'de 2 saat daha sonra $+500{ }^{\circ} \mathrm{C}^{\prime}$ de 4 saat yakılmıştır. Yakma işleminden sonra soğutulmaya bırakılan örnekler hassas terazide tartılmış ve kül miktarı (\%w/w) tayin edilmiştir.

\section{Istatistiki analiz}

Analiz ve ölçümlere ait veriler Minitab 18 bilgisayar paket programında varyans analizine tabi tutulmuştur. Ortalamalar arasındaki farklılıklar Tukey testine göre gruplandırılarak ifade edilmiştir.

\section{Bulgular ve Tartışma}

Farklı anaçlar üzerine aşılı sofralık üzüm çeşitlerinin 100 çekirdek ağırlığının 2.628-3.833 g aralığında değiştiği tespit edilmiştir. En ağır çekirdekler $1103 \mathrm{P}$ anacı üzerine aşılı Ata Sarısı üzüm çeşidinden, en hafif çekirdeklerin ise $110 \mathrm{R}$ anacı 
üzerine aşılı Trakya illkeren üzüm çeşidinden elde edilmiştir (Çizelge 1). Anaç-çeşit interaksiyonlarının 100 çekirdek ağırlığını değiştirdiği saptanmıştır. Yetiştiricilikte tercih edilen anacın; 100 çekirdek ağırlığı üzerine önemli bir etkisinin olmadığı belirlenmiştir.

1 kg'daki çekirdek sayısı bakımından anaççeşit interaksiyonlarının birbirlerinden farklılık gösterdiği saptanmıştır. 1 kg'ında en fazla çekirdek içeren çeşit 1103 P anacı üzerine aşılı Trakya IIlkeren, en az çekirdek içeren çeşit ise $110 \mathrm{R}$ anacı üzerine aşılı Ata Sarısı üzüm çeşididir. 100 çekirdek ağırlığı ile 1 kg'daki çekirdek sayısının tespiti, birbirini tamamlayan iki farklı özelliktir. Nitekim iki özelliğin birbiri ile negatif yönde kuvvetli bir korelasyon gösterdiği Şekil 2'de de görülmektedir. Buna karşın 100 çekirdek ağırlığından farklı olarak 1 kg'daki çekirdek sayısına anacın etki ettiği görülmektedir. $1103 \mathrm{P}$ anacına aşılı çeşitlerin ortalama 1 kg'daki çekirdek sayısı, $110 \mathrm{R}$ anacına aşılı olanlara kıyasla daha yüksek bulunmuştur.

Çizelge 1. Farklı anaçlar üzerine aşılı sofralık üzüm çeşitlerine ait çekirdeklerin pomolojik özellikleri.

\begin{tabular}{|c|c|c|c|c|c|c|}
\hline Anaç & Çeşit & $\begin{array}{c}100 \text { çek. ağ. } \\
\text { (g) }\end{array}$ & $\begin{array}{l}1 \text { kg çek. } \\
\text { say. (adet) }\end{array}$ & $\begin{array}{c}\text { Çekirdek nemi } \\
(\% \mathrm{w} / \mathrm{w})\end{array}$ & $\begin{array}{c}\text { Çekirdek eni } \\
(\mathrm{mm})\end{array}$ & $\begin{array}{c}\text { Çekirdek boyu } \\
\text { (mm) }\end{array}$ \\
\hline \multirow{5}{*}{$1103 \mathrm{P}$} & Red Globe & $3.198 b^{*}$ & $31083.3 \mathrm{f}$ & $5.78 \mathrm{a}$ & $4.07 \mathrm{abc}$ & $7.45 \mathrm{~b}$ \\
\hline & Trakya IIlkeren & $2.673 \mathrm{e}$ & 39241.7 a & $2.18 \mathrm{e}$ & $3.61 \mathrm{~cd}$ & $5.82 \mathrm{e}$ \\
\hline & Ata Sarısı & $3.833 \mathrm{a}$ & $26108.3 \mathrm{~h}$ & $3.70 \mathrm{c}$ & $4.16 a b$ & $6.75 \mathrm{~d}$ \\
\hline & $\begin{array}{l}\text { Hatun } \\
\text { Parmağı }\end{array}$ & $3.110 \mathrm{~b}$ & 31916.7 e & $4.53 \mathrm{~b}$ & $3.46 \mathrm{~d}$ & $5.99 \mathrm{e}$ \\
\hline & Horoz Karası & $2.773 \mathrm{de}$ & $37300.0 \mathrm{c}$ & $5.61 \mathrm{a}$ & $4.47 \mathrm{a}$ & $7.12 \mathrm{c}$ \\
\hline \multirow{5}{*}{$110 \mathrm{R}$} & Red Globe & $3.228 \mathrm{~b}$ & $31000.0 \mathrm{f}$ & $4.00 \mathrm{c}$ & $4.35 \mathrm{a}$ & $8.11 \mathrm{a}$ \\
\hline & Trakya IIlkeren & $2.628 \mathrm{e}$ & $38383.3 \mathrm{~b}$ & $3.04 \mathrm{~d}$ & $3.63 \mathrm{bcd}$ & $5.82 \mathrm{e}$ \\
\hline & Ata Sarısı & $3.663 \mathrm{a}$ & $27966.7 \mathrm{~g}$ & $2.75 \mathrm{~d}$ & $4.04 a b c$ & $6.49 \mathrm{~d}$ \\
\hline & $\begin{array}{l}\text { Hatun } \\
\text { Parmağı }\end{array}$ & $3.090 \mathrm{bc}$ & 32025.0 e & $4.10 \mathrm{bc}$ & $3.45 \mathrm{~d}$ & $6.09 \mathrm{e}$ \\
\hline & Horoz Karası & $2.895 \mathrm{~cd}$ & $35358.3 d$ & $5.73 \mathrm{a}$ & $4.20 \mathrm{a}$ & $6.72 \mathrm{~d}$ \\
\hline Genel & $1103 P$ & 3.117 ÖD & $33130.0 \mathrm{~A}$ & $4.36 \mathrm{~A}$ & 3.95 ÖD & 6.62 ÖD \\
\hline Ort. & $110 \mathrm{R}$ & 3.101 & 32946.7 B & $3.92 \mathrm{~B}$ & 3.93 & 6.65 \\
\hline
\end{tabular}

*Her bir sütunda farklı harflerle belirtilen ortalamalar istatistik olarak önemlidir $(\mathrm{P}<0.05)$.
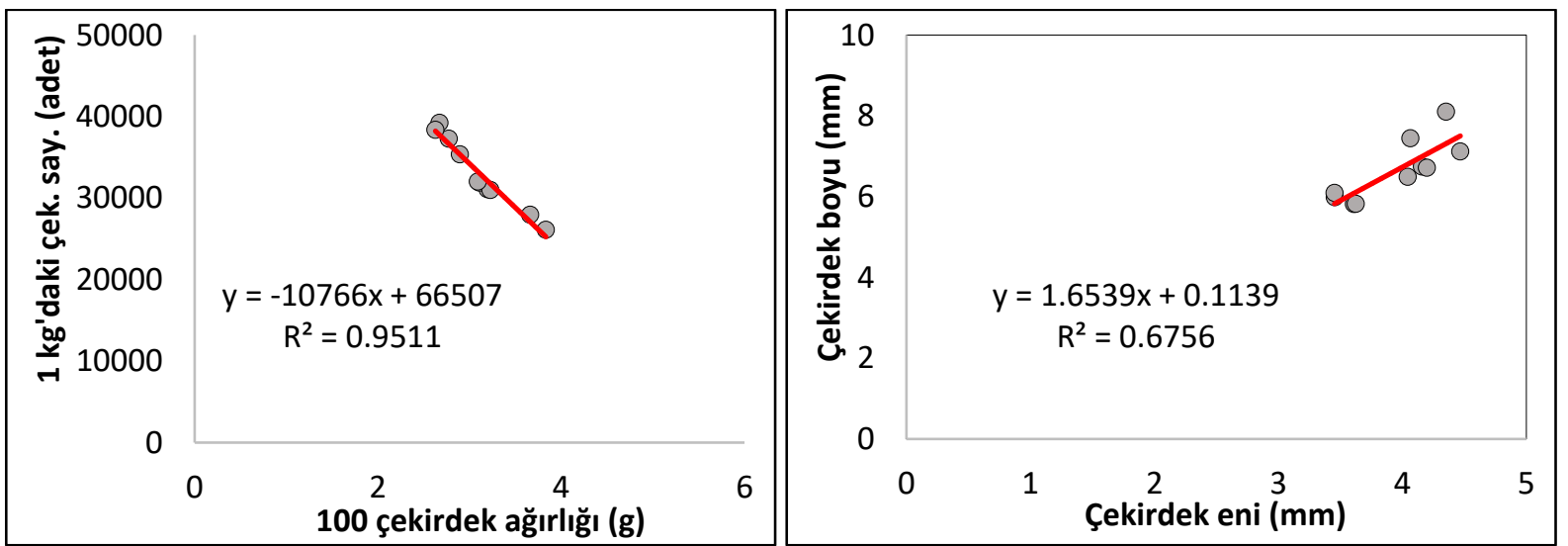

Şekil 2. Anaç-çeşit interaksiyonlarına ait 1 kg'daki çekirdek sayısı ile 100 çekirdek ağırlığı ilişkisi (a), çekirdek boyuçekirdek eni ilişkisi (b).

Çekirdek neminin farklı anaçlara aşılı üzüm çeşitlerinde birbirinden farklılık gösterdiği ve \%2.18 ile \%5.78 arasında değiştiği saptanmıştır. Anaçların üzerlerine aşılanmış üzüm çeşitlerinin çekirdeklerinde su birikimine etki ettiği görülmektedir. $1103 \mathrm{P}$ anacına aşılı çeşitlerin çekirdeklerinde daha fazla nem bulunduğu tespit edilmiştir. Literatürde $110 \mathrm{R}$ anacının, $1103 \mathrm{P}$ anacına göre kuraklığa daha toleranslı olduğunu belirten çalışmalar olmasına karşın (Serra ve ark., 2014); elde ettiğimiz çekirdek nemi bulguları bu durumun verim çağına ulaşmış sulanmayan bağlarda farklı olabileceğini göstermektedir. Nitekim Mccarthy ve ark. (1997), sulu koşullarda bu iki anacın üzerlerine aşılanan çeşitte benzer verimliliği sağladıklarını ancak kuraklık stresi altında 1103 P anacının 110 R anacına kıyasla daha yüksek verim verdiğini bildirmişlerdir. 
Çekirdek eni ve çekirdek boyunun anaç-çeşit interaksiyonlarına göre farklılık gösterdiği saptanmış olup; çekirdek eninin 3.45-4.47 mm, çekirdek boyunun ise $5.82-8.11 \mathrm{~mm}$ arasında değiştiği belirlenmiştir. Her iki özelliğe de bağda kullanılan anacın etkisinin olmadığı görülmüştür. Bununla birlikte çekirdek eni ile boyu arasında pozitif yönde doğrusal bir ilişki olduğu belirlenmiştir (Şekil 2). Uslu ve Dardeniz (2009)'de bu iki özellik arasında pozitif bir ilişki olduğunu bildirmişlerdir.

İncelenen üzüm çeşitlerinin üzerlerine aşılandıkları anaçlardan bağımsız olarak 100 çekirdek ağırlıkları incelendiğinde en ağır çekirdeklere sahip çeşidin Ata Sarısı (3.748 g), en hafif çekirdeklere sahip çeşidin ise Trakya ilkeren (2.650 g) üzüm çeşidi olduğu tespit edilmiştir (Çizelge 2). Elde edilen sonuçlar; daha önce şaraplık üzüm çeşitlerini inceleyen Uslu ve Dardeniz (2009)'e paralellik göstermesine karşın Fernandes ve ark. (2013) ile Kamiloğlu ve Üstün (2014)'ün bildirdikleri alt sınır değerlerinden daha düşük bulunmuştur. Ancak her iki çalışmada da, çekirdek ağırlığının incelenen üzüm çeşidine göre değişim gösterebileceği vurgulanmıştır.

1 kg'daki çekirdek sayısının incelenen üzüm çeşitlerinde farklılık gösterdiği belirlenmiştir. Anaç çeşit interaksiyonlarında da belirlenen; 100 çekirdek ağırlığı ile 1 kg'daki çekirdek sayısı arasındaki negatif ilişki çeşitlerde de gözlemlenmiştir. Çeşitler kabuk rengine göre sınıflandırıldığında; hem 100 çekirdek ağırlığı hem de 1 kg'daki çekirdek sayısı bakımından farklılık gösterdikleri saptanmıştır. Beyaz çeşitlerin, renkli çeşitlere kıyasla daha ağır çekirdeklere sahip oldukları görülmüştür.

Çizelge 2. Sofralık üzüm çeşitlerine ait çekirdeklerin pomolojik özellikleri.

\begin{tabular}{cccccc} 
Çeşit & $\begin{array}{c}\mathbf{1 0 0} \text { çek. ağ. } \\
\text { (g) }\end{array}$ & $\begin{array}{c}\text { 1 kg çek. } \\
\text { say. (adet) }\end{array}$ & $\begin{array}{c}\text { Çekirdek } \\
\text { nemi (\% w/w) }\end{array}$ & $\begin{array}{c}\text { Çekirdek eni } \\
\text { (mm) }\end{array}$ & $\begin{array}{c}\text { Çekirdek boyu } \\
\text { (mm) }\end{array}$ \\
\hline Red Globe & $3.213 \mathrm{~b}^{*}$ & $31041.7 \mathrm{~d}$ & $4.89 \mathrm{~b}$ & $4.21 \mathrm{a}$ & $7.78 \mathrm{a}$ \\
Trakya Illkeren & $2.650 \mathrm{~d}$ & $38812.5 \mathrm{a}$ & $2.61 \mathrm{e}$ & $3.62 \mathrm{~b}$ & $5.82 \mathrm{e}$ \\
Ata Sarısı & $3.748 \mathrm{a}$ & $27037.5 \mathrm{e}$ & $3.22 \mathrm{~d}$ & $4.10 \mathrm{a}$ & $6.62 \mathrm{c}$ \\
Hatun Parmağı & $3.100 \mathrm{~b}$ & $31970.8 \mathrm{c}$ & $4.32 \mathrm{c}$ & $3.45 \mathrm{~b}$ & $6.04 \mathrm{~d}$ \\
Horoz Karası & $2.848 \mathrm{c}$ & $36329.2 \mathrm{~b}$ & $5.67 \mathrm{a}$ & $4.33 \mathrm{a}$ & $6.92 \mathrm{~b}$ \\
\hline Renkli çeşitler ort. & $2.899 \mathrm{~B}$ & $35394.4 \mathrm{~A}$ & $4.39 \mathrm{O} \mathrm{D}$ & $4.05 \mathrm{~A}$ & $6.84 \mathrm{~A}$ \\
Beyaz çeşitler ort. & $3.424 \mathrm{~A}$ & $29504.2 \mathrm{~B}$ & 3.77 & $3.78 \mathrm{~B}$ & $6.33 \mathrm{~B}$ \\
\hline
\end{tabular}

*Her bir sütunda farklı harflerle belirtilen ortalamalar istatistik olarak önemlidir $(\mathrm{P}<0.05)$.

Çekirdeklerin nem içeriklerinin üzüm çeşidine göre değiştiği tespit edilmiştir. En yüksek nem içeriği Horoz Karası çeşidinde (\%5.67), en düşük nem içeriği ise Trakya ilkeren çeşidinde (\%2.61) bulunmuştur. Çeşidin kabuk renginin; çekirdeklerin nem içeriğini etkilemediği belirlenmiştir. Elde edilen bulgular (özellikle Horoz Karası çeşidinin incelenen diğer çeşitlere göre daha yüksek nem içerdiği bulgusu); Gök Tangolar ve ark. (2009) ile paralellik göstermektedir. Ayrıca çekirdeklerin nem içeriklerinin çeşide göre değiştiğini bildiren önceki çalışmalarla da uyum göstermektedir (Rababah ve ark., 2008; Yi ve ark., 2009; Mironeasa ve ark., 2010; Santos ve ark., 2011).

Çekirdek boyutlarının (en-boy); anaçtan bağımsız olarak çeşitlere göre farklılık gösterdiği belirlenmiştir. Red Globe üzüm çeşidinde en yüksek çekirdek boyu değeri $(7.78 \mathrm{~mm}$ ) elde edilmiştir. Bu çeşidin çekirdeklerinde gaga kısmının uzun olması bu durumun temel sebebidir. İncelenen çeşitlerde kabuk renginin çekirdek boyutlarını etkilediği; renkli çeşitlerin daha büyük çekirdeklere sahip olduğu tespit edilmiştir. Elde edilen bulgular önceki çalışmalarla paralellik göstermektedir (Uslu ve Dardeniz, 2009; Mironeasa ve ark., 2010).
Üzüm çekirdeklerinin sabit yağ içeriğinin \%3.91 ile \%24.76 arasında değiştiğini bildiren önceki çalışmalarla; araştırmamızda elde edilen sonuçlar uyuşmaktadır. Nitekim farklı anaçlar üzerine aşılı sofralık üzüm çeşitlerinin çekirdeklerinde sabit yağ içeriğinin \%9.92-16.30 (w/w) arasında değişim gösterdiği tespit edilmiştir (Çizelge 3). En yüksek sabit yağ miktarı; $1103 \mathrm{P}$ anacına aşılı Ata Sarısı üzüm çeşidi çekirdeklerinden elde edilmiştir. Bununla birlikte en düşük yağ miktarı; aynı anaç üzerine aşılı bir başka çeşit olan Horoz Karası üzüm çeşidinde saptanmıştır. Ayrıca $110 \mathrm{R}$ anacı üzerine aşılı Ata Sarısı üzüm çeşidinin de sabit yağ içeriğinin, aynı anaç üzerine aşılı diğer çeşitlere kıyasla daha yüksek bulunması; bu çeşidi diğer çeşitlerden ayıran genotipik bir özellik olarak öne çıkmaktadır. Anaçların çekirdeklerin sabit yağ içeriğine olan etkisi önemsiz bulunmuştur.

Çekirdeklerin kül miktarı bakımından anaççeşit interaksiyonlarından elde edilen örnekler arasında istatistiki olarak farklılık olmadığı belirlenmiştir. Ayrıca anaçlar da çeşitlerden bağımsız değerlendirildiğinde; çekirdeklerin kül miktarı üzerine etkilerinin olmadığı görülmüştür.

Farklı anaçlar üzerine aşılı üzüm çeşitlerinin protein miktarlarının birbirinden farklılık gösterdiği belirlenmiştir. Hatun Parmağı üzüm çeşidi 
çekirdeklerinin protein miktarı; her iki anaç üzerinde de diğerlerine göre yüksek bulunmuş olup, kullanılan anacın bu çeşidi etkilemediği tespit edilmiştir. Her ne kadar Hatun Parmağı üzüm çeşidinin çekirdeklerinde protein miktarı anaç farklılığından etkilenmemişse de; $1103 \mathrm{P}$ anacına aşılı çeşitlerin ortalama protein miktarı, $110 \mathrm{R}$ anacına aşılananlara göre daha yüksek bulunmuştur. Bu farklılık çeşitlerin topraktan su ya da bitki besin elementi alımlarındaki değişkenlikten kaynaklanmış olabilir.

İncelenen anaç-çeşit kombinasyonlarının endosperm gelişimini tamamlamış çekirdek oranı bakımından birbirlerinden farklı olduğu saptanmıştır. Bu özellik bakımından en yüksek değer (\%96.67) incelenen her iki anaçta da Ata Sarısı üzüm çeşidinden elde edilmiştir. Anaçlar arasında ise önemli bir farklılık belirlenememiştir.

Çizelge 3. Farklı anaçlar üzerine aşılı sofralık üzüm çeşitlerine ait çekirdeklerin kül miktarı, endosperm gelişimi, sabit yağ ve protein içeriği.

\begin{tabular}{|c|c|c|c|c|c|}
\hline Anaç & Çeşit & $\begin{array}{l}\text { Sabit yağ } \\
(\% \mathrm{w} / \mathrm{w})\end{array}$ & $\begin{array}{c}\text { Kül miktarı } \\
(\% \mathrm{w} / \mathrm{w})\end{array}$ & $\begin{array}{c}\text { Protein mikt. } \\
(\% \mathrm{w} / \mathrm{w})\end{array}$ & $\begin{array}{c}\text { Endosperm geliş. } \\
\text { tam. çek. (\%) }\end{array}$ \\
\hline \multirow{5}{*}{1103 P } & Red Globe & $14.65 \mathrm{ab}^{*}$ & 3.08 ÖD & $6.87 \mathrm{ef}$ & 53.34 cde \\
\hline & Trakya ilkeren & $14.41 \mathrm{ab}$ & 3.07 & $8.05 \mathrm{c}$ & $78.34 \mathrm{abc}$ \\
\hline & Ata Sarısı & $16.30 \mathrm{a}$ & 3.01 & $9.00 \mathrm{~b}$ & $96.67 \mathrm{a}$ \\
\hline & $\begin{array}{l}\text { Hatun } \\
\text { Parmağı }\end{array}$ & $14.70 \mathrm{ab}$ & 2.83 & $9.62 \mathrm{a}$ & $81.67 \mathrm{ab}$ \\
\hline & Horoz Karası & $9.92 \mathrm{~d}$ & 2.97 & $7.51 \mathrm{~d}$ & $41.67 \mathrm{e}$ \\
\hline \multirow{5}{*}{$110 \mathrm{R}$} & Red Globe & $13.19 \mathrm{bc}$ & 2.81 & $6.47 \mathrm{f}$ & $51.67 \mathrm{de}$ \\
\hline & Trakya ilkeren & $14.51 \mathrm{ab}$ & 2.89 & $8.21 \mathrm{c}$ & $68.34 \mathrm{bcd}$ \\
\hline & Ata Sarısı & $15.56 \mathrm{ab}$ & 3.70 & $8.82 \mathrm{~b}$ & $96.67 \mathrm{a}$ \\
\hline & $\begin{array}{l}\text { Hatun } \\
\text { Parmağı }\end{array}$ & $13.17 b c$ & 3.13 & $9.95 \mathrm{a}$ & $88.34 a b$ \\
\hline & Horoz Karası & $11.28 \mathrm{~cd}$ & 2.65 & $6.96 \mathrm{e}$ & 66.67 bcde \\
\hline Genel & $1103 P$ & 14.00 ÖD & 2.99 ÖD & $8.21 \mathrm{~A}$ & 70.34 ÖD \\
\hline Ort. & $110 \mathrm{R}$ & 13.54 & 3.04 & $8.08 \mathrm{~B}$ & 74.34 \\
\hline
\end{tabular}

*Her bir sütunda farklı harflerle belirtilen ortalamalar istatistik olarak önemlidir $(\mathrm{P}<0.05)$.

İncelenen çeşitlerden Ata Sarısı; çekirdekte en yüksek (\%15.93 w/w) sabit yağ içeriğine sahip üzüm çeşidi olarak belirlenmiştir (Çizelge 4). Bu çeşidi sırasıyla Trakya Illkeren, Hatun Parmağı, Red Globe ve Horoz Karası üzüm çeşitleri takip etmiştir. Çalışmada yer alan bütün çeşitlerin sabit yağ içerikleri; daha önce farklı çalışmalarda belirtilen sınır değerlerinin içerisinde bulunmuştur. Red Globe çeşidi çekirdeklerinin, Horoz Karası çeşidinin çekirdeklerine göre daha fazla sabit yağ içerdiği bulgusu Sabır ve ark. (2012) tarafından da bildirilmiştir. Benzer bir şekilde Hatun Parmağı çeşidinin, Horoz Karası çeşidine göre çekirdekte daha yüksek miktarda sabit yağ içerdiği bulgusu Sağdıçoğlu (2018) tarafından da bildirilmiştir. Bununla birlikte Horoz Karası çeşidinin incelendiği bir başka çalışmada; bu çeşidin çekirdeklerinde \%14.29 yağ bulunduğu belirtilmiştir. Çalışmamızda daha düşük değerlerin tespiti; yetiştiricilik yapılan ekolojilerin ya da bağlarda uygulanan kültürel işlemlerin farklılığından kaynaklanmış olabilir. Sabit yağ içeriğinin; incelenen üzüm çeşidinin kabuk rengine göre değişim gösterdiği, beyaz üzüm çeşitlerinin renklilere kıyasla daha fazla yağa sahip oldukları saptanmıştır.

Çizelge 4. Farklı anaçlar üzerine aşılı renkli ve beyaz sofralık üzüm çeşitlerine ait çekirdeklerin kül miktarı, endosperm gelişimi, sabit yağ ve protein içeriği.

\begin{tabular}{ccccc}
\hline Çeşit & $\begin{array}{c}\text { Sabit yağ } \\
\text { (\% w/w) }\end{array}$ & $\begin{array}{c}\text { Kül miktarı } \\
\text { (\% w/w) }\end{array}$ & $\begin{array}{c}\text { Protein mikt. } \\
\text { (\% w/w) }\end{array}$ & $\begin{array}{c}\text { Endosperm geliş. } \\
\text { tam. çek. (\%) }\end{array}$ \\
\hline Red Globe & $13.92 \mathrm{~b} *$ & $2.95 \mathrm{ÖD}$ & $6.67 \mathrm{e}$ & $52.50 \mathrm{c}$ \\
Trakya Illkeren & $14.46 \mathrm{ab}$ & 2.98 & $8.13 \mathrm{c}$ & $73.34 \mathrm{~b}$ \\
Ata Sarısı & $15.93 \mathrm{a}$ & 3.36 & $8.91 \mathrm{~b}$ & $96.67 \mathrm{a}$ \\
Hatun Parmağı & $13.94 \mathrm{~b}$ & 2.98 & $9.78 \mathrm{a}$ & $85.00 \mathrm{ab}$ \\
Horoz Karası & $10.60 \mathrm{c}$ & 2.81 & $7.24 \mathrm{~d}$ & $54.17 \mathrm{c}$ \\
\hline Renkli çeşitler ort. & $12.99 \mathrm{~B}$ & $2.91 \mathrm{O}$ ÖD & $7.35 \mathrm{~B}$ & $60.01 \mathrm{~B}$ \\
Beyaz çeşitler ort. & $14.93 \mathrm{~A}$ & 3.17 & $9.35 \mathrm{~A}$ & $90.84 \mathrm{~A}$ \\
\hline
\end{tabular}

*Her bir sütunda farklı harflerle belirtilen ortalamalar istatistik olarak önemlidir $(\mathrm{P}<0.05)$. 
Çekirdeklerin kül miktarının tek başına çeşide ve anaca göre önemli bir değişim göstermediği belirlenmiştir. Ayrıca tespit edilen kül miktarları daha önceki araştırmalarda elde edilen bulgularla benzerlik göstermektedir (Yoo ve ark., 1984; Kamel ve ark., 1985; Rababah ve ark., 2008; Santos ve ark., 2011).

Protein miktarı bakımından çeşitlere ait çekirdeklerin birbirinden farklı olduğu tespit edilmiştir. Hatun Parmağı üzüm çeşidi çekirdeklerinde en yüksek (\%9.78 \%w/w) protein miktarı saptanmıştır. Beyaz üzüm çeşitlerinin çekirdeklerinde, renklilerinkine kıyasla daha yüksek miktarda protein bulunduğu görülmüştür. Benzeri bulguları; Yoo ve ark. (1984), Kamel ve ark. (1985), Gök Tangolar ve ark. (2009), Mironeasa ve ark. (2010), Santos ve ark. (2011), Sağdıçoğlu (2018)'da bildirmiştir.

Endosperm gelişimini tamamlamış çekirdeklerin oranı, incelenen üzüm çeşidine bağlı olarak değişim göstermiştir. Bununla birlikte yüksek yağ ve protein oranına sahip çeşitlerin çekirdeklerinin aynı zamanda da yüksek endosperm gelişimi gösterdikleri görülmüştür. Bu özellik bakımından beyaz üzüm çeşitlerinin çekirdeklerinin renklilere göre daha yüksek değerlere sahip oldukları tespit edilmiştir.

Yağ asidi tayinlerinde elde edilen örnek bir kromatogram Şekil 3'te sunulmuştur. Farklı anaçlar üzerine aşılanmış sofralık üzüm çeşitlerinde 18 farklı yağ asidi tespit edilmiştir (Çizelge 5). Ancak tespit edilen yağ asitlerinin tamamı; incelenen tüm anaççeşit interaksiyonlarında mevcut bulunmamaktadırlar. Daha önce bu konuda çalışmış olan araştırmacılar; üzüm çekirdeği yağ asidi kompozisyonunun 5-34 farklı yağ asidini içerdiğini bildirmişlerdir (Göktürk Baydar ve ark., 2007; Yi ve ark., 2009; Özkaya ve ark., 2014). Çekirdeğin içerdiği yağ asitlerinin incelenen üzüm çeşitlerine göre farklılık gösterdiği bulgusu; önceki çalışmalarla paralellik göstermektedir.

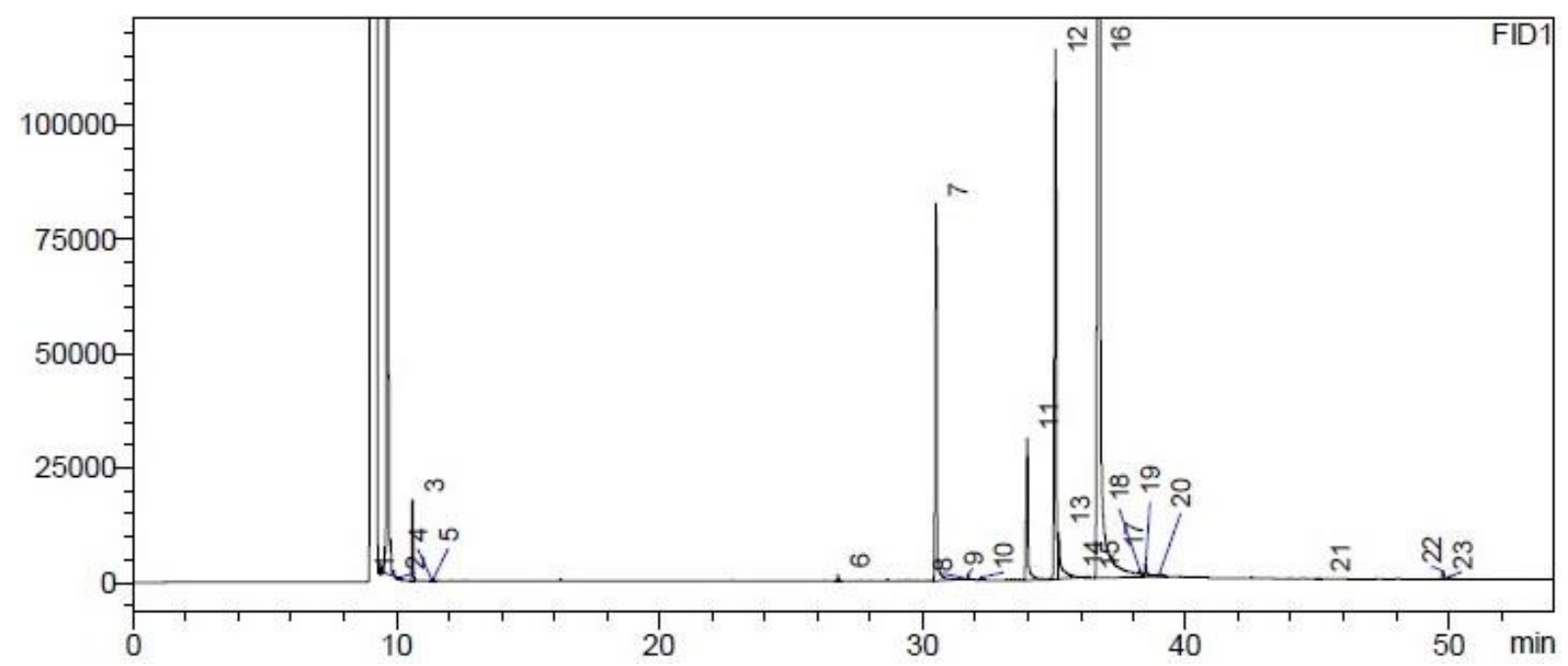

Şekil 3. $1103 \mathrm{P}$ anacına aşılı Trakya İlkeren çeşidinin yağ asidi tayinine ait kromatogram.

1-2-3-Bütirik asit (C4:0) 4-5-Kaproik asit (C6:0) 6-Miristik asit (C14:0) 7-Palmitik asit (C16:0) 8-9-Palmitoleik asit (C16:1) 10-Heptadekanoik asit (C17:0) 11-Stearik asit (C18:0) 12-13-Oleik asit (C18:1n-9c) 14-15- Trans-linoleladik asit (C18:2n-6t) 16- Linoleik asit (C18:2n-6c) 17-Araşidik asit (C20:0) 18-19-Eikosenoik asit (C20:1) 20Heneikosanoik asit (21:0) 21-Dokosadienoik asit (C22:2) 22-Eikosapentaeonik asit (C20:5n-3) EPA 23Dakosahexaenoik asit (C22:6n-3)DHA.

Çalışmada, incelenen farklı anaçlar üzerine aşılı sofralık üzüm çeşitlerine ait çekirdeklerin; bütirik asit (C4:0), kaproik asit (C6:0), heptadekanoik (margarik) asit (C17:0), eikosenoik (gadoleik) asit (C20:1), heneikosanoik asit (C21:0), eikosapentaenoik asit (C20:5n-3), nervonik asit (C24:1) içerikleri değişim göstermesine karşın; bu farklılıklar istatistiki olarak $\mathrm{P}<0.05$ önem seviyesinde anlamsız bulunmuştur.

İncelenen bütün anaç-çeşit interaksiyonlarında en yüksek miktarda (\%53.84 -
67.97) bulunan yağ asidi linoleik asit (C18:2n-6) olarak saptanmıştır. Bunu sırasıyla Oleik asit (C18:1n-9) \%16.09 - 31.52, palmitik asit (C16:0) \%8.16 - 10.40 ve stearik asit (C18:0) \%2.94 - 4.39 takip etmiştir. Yağ asitleri arasında saptanan bu sıralama (linoleik >oleik>palmitik>stearik) daha önce yapılan çalışmalarla uyum içerisindedir. En yüksek linoleik asit miktarı 1103 P anacı üzerine aşılı Trakya İlkeren üzüm çeşidinde, en yüksek oleik asit miktarı $110 \mathrm{R}$ anacı üzerine aşılı Hatun Parmağı üzüm çeşidinde saptanmıştır. Her iki anaç üzerine 
aşılı Horoz Karası üzüm çeşidinin çekirdeklerindeki palmitik asit ve linoleik asit içerikleri, Hatun Parmağı üzüm çeşidi çekirdeklerine göre daha yüksek bulunmuştur. Bununla birlikte, Hatun Parmağı üzüm çeşidinin çekirdeklerinden elde edilen sabit yağlarda stearik asit ve oleik asit içerikleri; her iki anaç üzerinde de Horoz Karası üzüm çeşidinden elde edilen sabit yağlara kıyasla daha yüksek bulunmuştur.

Toplam doymuş yağ asidi ( $\Sigma$ SFA), toplam tekli doymamış yağ asidi ( $\Sigma$ MUFA) ve toplam çoklu doymamış yağ asidi ( $\Sigma$ PUFA) miktarlarının anaççeşit interaksiyonlarına göre değişim gösterdiği tespit edilmiştir. Buna göre $\Sigma$ SFA \%13.75-17.22, $\Sigma$ MUFA \%16.61-31.99 ve $\Sigma$ PUFA \%53.99-68.40 arasında değişim göstermiştir. Benzer bir şekilde toplam doymamış yağ asidi ( $\Sigma$ UFA) miktarının da (\%82.78-86.26) anaç-çeşit interaksiyonlarına göre değişim gösterdiği belirlenmiştir. Bu özellik bakımından en yüksek değer $110 \mathrm{R}$ anacına aşılı Ata Sarısı üzüm çeşidinden elde edilmiştir. Ayrıca her iki anaç üzerinde de Hatun Parmağı üzüm çeşidinden elde edilen $\Sigma$ UFA miktarlarına ait ortalamalar hem birbirleri ile hem de 110 R-Ata Sarısı ile benzer bulunmuştur. $\Sigma$ PUFA/ $\Sigma$ SFA oranı; anaç-çeşit interaksiyonlarına göre değişim göstermemektedir.
Elde ettiğimiz bulgular; anaçtan bağımsız olarak değerlendirildiğinde de incelenen tüm çeşitlerde en yüksek oranda bulunan yağ asidinin linoleik asit olduğunu (\%54.05-67.40) ortaya koymuştur (Çizelge 6). En yüksek linoleik asit miktarı Trakya Illkeren üzüm çeşidinin çekirdeklerinde saptanmıştır. Ayrıca çeşitlerin çekirdeklerinde linoleik asit içeriğinin birbirinden farklı olduğu da belirlenmiştir. Bu yönüyle çalışmamız, önceki çalışmalardan elde edilen sonuçlarla paralellik göstermektedir (Yoo ve ark., 1984; Ohnishi ve ark., 1990; Göktürk Baydar ve Akkurt, 2001; Beveridge ve ark., 2005; Göktürk Baydar ve ark., 2007; Yi ve ark., 2009; Pardo ve ark., 2009; Uslu ve Dardeniz, 2009; Sabır ve ark., 2012; Demirtaş ve ark., 2013; Fernandes ve ark., 2013; Lachman ve ark., 2015). Çalışmanın yürütüldüğü ekolojik koşullarda benzeri bir çalışma yapan Sağdıçoğlu (2018); Hatun Parmağı üzüm çeşidi çekirdeklerinin, Horoz Karası çekirdeklerine göre daha yüksek miktarda linoleik asit içerdiğini bildirmiştir. İki çalışmadan elde edilen bulguların farklı olmasının; örneklerin alındığı bağlarda uygulanan kültürel işlemlerin (sulama, budama, gübreleme vb.) değişiklik göstermesinden ya da örnek alınan yılın etkisinden kaynaklanmış olabileceği düşünülmektedir.

Çizelge 6. Üzüm çeşitlerine ait çekirdeklerin yağ asidi kompozisyonları.

\begin{tabular}{|c|c|c|c|c|c|}
\hline Yağ Asidi (\%) & $\begin{array}{c}\text { Red } \\
\text { Globe }\end{array}$ & $\begin{array}{l}\text { Trakya } \\
\text { ilkeren }\end{array}$ & $\begin{array}{c}\text { Ata } \\
\text { Sarısı }\end{array}$ & $\begin{array}{c}\text { Hatun } \\
\text { Parmağı }\end{array}$ & $\begin{array}{l}\text { Horoz } \\
\text { Karası }\end{array}$ \\
\hline $\mathrm{C} 4: 0$ & $2.51 a b^{*}$ & $1.58 \mathrm{ab}$ & $1.51 \mathrm{~b}$ & $1.72 a b$ & $2.78 \mathrm{a}$ \\
\hline C6:0 & 0.13 ÖD & 0.14 & 0.08 & 0.08 & 0.12 \\
\hline C14:0 & $0.10 \mathrm{a}$ & $0.09 a$ & $0.11 \mathrm{a}$ & $0.06 \mathrm{~b}$ & $0.08 \mathrm{a}$ \\
\hline C16:0 & $9.66 a b$ & 8.76 bc & $9.24 a b c$ & $8.46 \mathrm{c}$ & $9.93 \mathrm{a}$ \\
\hline C16:1 & $0.20 \mathrm{a}$ & $0.14 \mathrm{~b}$ & $0.20 \mathrm{a}$ & $0.16 \mathrm{~b}$ & $0.22 \mathrm{a}$ \\
\hline C17:0 & 0.06 ÖD & 0.06 & 0.05 & 0.04 & 0.04 \\
\hline $\mathrm{C} 17: 1$ & $0.00 \mathrm{c}$ & 0.01 bc & $0.02 a b$ & $0.03 a$ & $0.00 \mathrm{c}$ \\
\hline C18:0 & $3.53 \mathrm{~b}$ & $4.32 \mathrm{a}$ & $3.17 \mathrm{c}$ & $3.55 \mathrm{~b}$ & $3.15 \mathrm{c}$ \\
\hline C18:1 cis (n-9) & 19.52 c & $16.42 \mathrm{~d}$ & $25.41 \mathrm{~b}$ & $31.30 \mathrm{a}$ & $20.00 \mathrm{c}$ \\
\hline C18:2 trans $(n-6)$ & $0.01 \mathrm{~b}$ & $0.10 a$ & $0.03 a b$ & $0.02 b$ & $0.00 \mathrm{~b}$ \\
\hline C18:2 cis (n-6) & $63.36 \mathrm{~b}$ & $67.40 \mathrm{a}$ & $59.50 \mathrm{c}$ & $54.05 \mathrm{~d}$ & $63.09 \mathrm{bc}$ \\
\hline C20:0 & $0.10 \mathrm{a}$ & $0.08 \mathrm{ab}$ & $0.06 \mathrm{~b}$ & $0.07 a b$ & $0.05 \mathrm{~b}$ \\
\hline C20:1 & $0.36 a b$ & $0.35 a b$ & $0.33 a b$ & $0.30 \mathrm{~b}$ & $0.38 a$ \\
\hline$C 20: 2$ & 0.00 ÖD & 0.01 & 0.00 & 0.00 & 0.00 \\
\hline $\mathrm{C} 21: 0$ & 0.03 ÖD & 0.03 & 0.00 & 0.02 & 0.00 \\
\hline$C 20: 5(n-3)$ & 0.00 ÖD & 0.01 & 0.00 & 0.01 & 0.00 \\
\hline$C 22: 6(n-3)$ & $0.41 a b$ & $0.46 a$ & $0.29 \mathrm{abc}$ & $0.14 \mathrm{c}$ & $0.16 \mathrm{bc}$ \\
\hline $\mathrm{C} 24: 1$ & 0.03 ÖD & 0.04 & 0.03 & 0.01 & 0.00 \\
\hline$\sum$ SFA & $16.12 \mathrm{a}$ & $15.07 \mathrm{ab}$ & $14.20 \mathrm{~b}$ & $14.01 \mathrm{~b}$ & $16.15 \mathrm{a}$ \\
\hline$\Sigma$ MUFA & $20.10 \mathrm{c}$ & $16.96 \mathrm{~d}$ & $25.99 \mathrm{~b}$ & 31.78 a & $20.60 \mathrm{c}$ \\
\hline$\Sigma$ PUFA & $63.78 \mathrm{~b}$ & $67.97 a$ & $59.82 \mathrm{c}$ & $54.21 d$ & $63.25 \mathrm{bc}$ \\
\hline$\Sigma$ UFA & $83.88 \mathrm{~b}$ & $84.93 a b$ & $85.80 \mathrm{a}$ & 85.99 a & $83.85 b$ \\
\hline PUFA/SFA & $4.01 \mathrm{ab}$ & $4.56 \mathrm{a}$ & $4.23 a b$ & $3.88 \mathrm{~b}$ & $3.94 \mathrm{ab}$ \\
\hline
\end{tabular}

*Her bir satırda farklı harflerle belirtilen ortalamalar istatistik olarak önemlidir $(\mathrm{P}<0.05)$. 
Çizelge 5. Farklı anaçlar üzerine aşılı sofralık üzüm çeşitlerine ait çekirdeklerin yağ asidi kompozisyonları.

\begin{tabular}{|c|c|c|c|c|c|c|c|c|c|c|}
\hline \multirow{2}{*}{ Yağ asidi (\%) } & \multicolumn{5}{|c|}{$1103 \mathrm{P}$} & \multicolumn{5}{|c|}{$110 R$} \\
\hline & Red Globe & Trakya ilkeren & Ata Sarısı & Hatun P. & Horoz Karası & Red Globe & Trakya ilkeren & Ata Sarısı & Hatun Parmağı & Horoz Karası \\
\hline C4:0 & 2.00 ÖD* & 1.39 & 1.36 & 1.30 & 2.45 & 3.02 & 1.78 & 1.66 & 2.14 & 3.11 \\
\hline C6:0 & 0.10 ÖD & 0.07 & 0.06 & 0.06 & 0.11 & 0.16 & 0.22 & 0.09 & 0.10 & 0.13 \\
\hline $\mathrm{C} 14: 0$ & $0.09 a b$ & $0.09 a b$ & $0.10 a b$ & $0.06 \mathrm{~b}$ & $0.08 a b$ & $0.12 \mathrm{a}$ & $0.09 a b$ & $0.12 \mathrm{a}$ & $0.05 \mathrm{~b}$ & $0.09 a b$ \\
\hline C16:0 & $9.19 b-d$ & $8.86 \mathrm{~cd}$ & $9.74 \mathrm{abc}$ & $8.76 \mathrm{~cd}$ & $10.40 \mathrm{a}$ & $10.13 a b$ & $8.66 \mathrm{~cd}$ & $8.73 \mathrm{~cd}$ & $8.16 \mathrm{~d}$ & $9.46 a b c$ \\
\hline C16:1 & 0.19 a-e & $0.14 \mathrm{e}$ & $0.20 \mathrm{a}-\mathrm{d}$ & 0.16 b-e & $0.21 \mathrm{ab}$ & $0.20 \mathrm{a}-\mathrm{d}$ & $0.15 \mathrm{de}$ & $0.20 \mathrm{abc}$ & 0.15 cde & $0.23 \mathrm{a}$ \\
\hline C17:0 & 0.05 ÖD & 0.06 & 0.05 & 0.06 & 0.05 & 0.06 & 0.06 & 0.04 & 0.03 & 0.03 \\
\hline C17:1 & $0.00 \mathrm{~b}$ & $0.01 a b$ & $0.02 a b$ & $0.04 \mathrm{a}$ & $0.00 \mathrm{~b}$ & $0.00 \mathrm{~b}$ & $0.00 \mathrm{~b}$ & $0.02 a b$ & $0.02 a b$ & $0.00 \mathrm{~b}$ \\
\hline C18:0 & $3.49 \mathrm{bcd}$ & $4.39 \mathrm{a}$ & $3.27 \mathrm{bcd}$ & $3.65 b$ & $3.36 \mathrm{bcd}$ & $3.57 \mathrm{bc}$ & $4.25 \mathrm{a}$ & $3.06 \mathrm{~cd}$ & $3.45 \mathrm{bcd}$ & $2.94 \mathrm{~d}$ \\
\hline C18:1 c (n-9) & 19.43 cde & $16.09 \mathrm{e}$ & $27.46 a b$ & $31.08 \mathrm{a}$ & $20.59 \mathrm{~cd}$ & 19.60 cde & $16.75 \mathrm{de}$ & 23.36 bc & $31.52 \mathrm{a}$ & $19.41 \mathrm{cde}$ \\
\hline C18:2 t (n-6) & $0.02 \mathrm{~b}$ & $0.16 \mathrm{a}$ & $0.03 \mathrm{~b}$ & $0.03 \mathrm{~b}$ & $0.00 \mathrm{~b}$ & $0.00 \mathrm{~b}$ & $0.04 a b$ & $0.02 \mathrm{~b}$ & $0.00 \mathrm{~b}$ & $0.00 \mathrm{~b}$ \\
\hline$C 18: 2 c(n-6)$ & $64.56 \mathrm{ab}$ & $67.97 a$ & $57.18 \mathrm{~cd}$ & $54.25 d$ & $62.23 a b c$ & $62.15 \mathrm{abc}$ & $66.83 a b$ & $61.83 \mathrm{bc}$ & $53.84 d$ & $63.94 a b$ \\
\hline $\mathrm{C} 20: 0$ & $0.10 \mathrm{a}$ & $0.08 a b$ & $0.06 a b$ & $0.07 a b$ & $0.07 a b$ & $0.10 \mathrm{a}$ & $0.08 a b$ & $0.05 a b$ & $0.08 a b$ & $0.04 \mathrm{~b}$ \\
\hline C20:1 & 0.36 ÖD & 0.36 & 0.33 & 0.30 & 0.37 & 0.36 & 0.34 & 0.33 & 0.30 & 0.38 \\
\hline $\mathrm{C} 20: 2$ & $0.00 \mathrm{~b}$ & $0.01 \mathrm{a}$ & $0.00 \mathrm{~b}$ & $0.00 \mathrm{~b}$ & $0.00 \mathrm{~b}$ & $0.00 \mathrm{~b}$ & $0.00 \mathrm{~b}$ & $0.00 \mathrm{~b}$ & $0.00 \mathrm{~b}$ & $0.00 \mathrm{~b}$ \\
\hline C21:0 & 0.00 ÖD & 0.05 & 0.00 & 0.04 & 0.00 & 0.07 & 0.00 & 0.00 & 0.00 & 0.00 \\
\hline$C 20: 5(n-3)$ & 0.00 ÖD & 0.02 & 0.00 & 0.01 & 0.00 & 0.00 & 0.00 & 0.00 & 0.00 & 0.00 \\
\hline$C 22: 6(n-3)$ & $0.39 a b$ & $0.25 a b$ & $0.14 b$ & $0.13 b$ & $0.07 \mathrm{~b}$ & $0.43 a b$ & $0.67 \mathrm{a}$ & $0.44 a b$ & $0.15 b$ & $0.25 a b$ \\
\hline $\mathrm{C} 24: 1$ & 0.02 ÖD & 0.00 & 0.00 & 0.01 & 0.00 & 0.04 & 0.08 & 0.06 & 0.00 & 0.00 \\
\hline$\sum$ SFA & $15.03 \mathrm{ab}$ & $14.99 \mathrm{ab}$ & $14.65 a b$ & $13.99 \mathrm{~b}$ & $16.52 \mathrm{ab}$ & $17.22 \mathrm{a}$ & $15.14 \mathrm{ab}$ & $13.75 \mathrm{~b}$ & $14.02 \mathrm{~b}$ & $15.78 \mathrm{ab}$ \\
\hline$\Sigma$ MUFA & $20.01 \mathrm{cde}$ & $16.61 \mathrm{e}$ & $27.99 a b$ & $31.58 \mathrm{a}$ & $21.18 \mathrm{~cd}$ & 20.20 cde & $17.32 \mathrm{de}$ & 23.97 bc & 31.99 a & 20.02 cde \\
\hline$\sum$ PUFA & $64.97 a b$ & $68.40 \mathrm{a}$ & $57.35 \mathrm{~cd}$ & $54.42 d$ & $62.30 \mathrm{bc}$ & $62.58 \mathrm{bc}$ & $67.54 a b$ & $62.28 \mathrm{bc}$ & $53.99 d$ & $64.19 a b$ \\
\hline$\Sigma$ UFA & $84.98 a b$ & $85.01 \mathrm{ab}$ & $85.35 a b$ & $86.00 \mathrm{a}$ & $83.48 a b$ & $82.78 b$ & $84.86 a b$ & $86.26 \mathrm{a}$ & $85.98 \mathrm{a}$ & $84.22 a b$ \\
\hline PUFA/SFA & 4.37 ÖD & 4.60 & 3.91 & 3.89 & 3.77 & 3.64 & 4.52 & 4.54 & 3.86 & 4.10 \\
\hline
\end{tabular}

*Her bir satırda farklı harflerle belirtilen ortalamalar istatistik olarak önemlidir $(\mathrm{P}<0.05)$. 
Incelenen çeşitlerin en yüksek miktarda içerdikleri ikinci yağ asidi; oleik asit (\%16.42-31.30) olarak belirlenmiştir. Linoleik asidin tersine; oleik asit içeriği bakımından en yüksek değerlere sahip çekirdekler Hatun Parmağı üzüm çeşidinden, en düşük olanlar ise Trakya illkeren üzüm çeşidinden elde edilmiştir. Çekirdeklerindeki oleik asit miktarı bakımından, üzüm çeşitleri birbirinden farklılık göstermiştir. Yağ asidi miktarı bakımından oleik asidi sırasıyla palmitik asit (\%8.46-9.93), stearik asit (\%3.15-4.32) ve bütirik asit (\%1.51-2.78) takip etmiştir. Çeşitlerin, çekirdeklerinde tespit edilen yağ asitlerinden kaproik asit (C6:0), heptadekanoik (margarik) asit (C17:0), eikosadienoik asit (C20:2), heneikosanoik asit (C21:0), eikosapentaenoik asit (C20:5n-3), nervonik asit (C24:1) içerikleri bakımından birbirlerinden farklı olmadığı saptanmıştır.

Toplam doymuş ve toplam doymamış yağ asidi kompozisyonları bakımından Red Globe ve Horoz Karası üzüm çeşitleri arasında farklılık olmadığı tespit edilmiştir. En yüksek $\Sigma$ MUFA değeri Hatun Parmağı üzüm çeşidinde, en yüksek $\Sigma$ PUFA değeri ise Trakya illkeren üzüm çeşidinde belirlenmiştir.
Hatun Parmağı (\%85.99) ve Ata Sarısı (\%85.80); $\Sigma$ UFA içeriklerinin diğerlerine göre yüksek bulunması sayesinde öne çıkan çeşitler olmuşlardır. Ayrıca PUFA/SFA oranının üzüm çeşitlerine göre değişim gösterdiği belirlenmiştir.

Incelenen çekirdeklerde yağ asitleri miktarının büyük çoğunluğunu bağda kullanılan anacın etkilemediği saptanmıştır. Özellikle üzüm çekirdeği yağında yoğun olarak bulunan; linoleik asit, oleik asit, palmitik asit ve stearik asidin farklı anaçların etkisi altında değişmediği tespit edilmiştir (Çizelge 7). Bununla birlikte daha az oranlarda bulunan; bütirik asit (C4:0), kaproik asit (C6:0), heptadekanoik (margarik) asit (C17:0), eikosapentaenoik asit (C20:5n-3), dokosaheksaenoik asit (C22:6n-3) ve nervonik asit (C24:1) anacın etkisiyle değişim göstermiştir. Bu yağ asitlerinden bütirik asit ve eikosapentaenoik asidin değişimi dikkat çekmektedir. Her iki yağ asidi de 110 $R$ anacı üzerine aşılı çeşitlerde daha yüksek miktarlarda tespit edilmiştir. Ayrıca ¿SFA, ¿MUFA, ¿PUFA, ¿UFA ve PUFA/SFA bakımından da anaçlar arasında farklılık olmadığı belirlenmiştir.

Çizelge 7. Asma anaçlarının ve çeşitlerin renkliliklerinin çekirdeklerin yağ asidi kompozisyonlarına üzerine bağımsız etkileri.

\begin{tabular}{ccccc}
\hline Yağ Asidi (\%) & $\mathbf{1 1 0 3} \mathbf{P}$ & $\mathbf{1 1 0} \mathbf{R}$ & Renkli çeşitler & Beyaz çeşitler \\
\hline C4:0 & $1.70 \mathrm{~b}^{*}$ & $2.34 \mathrm{a}$ & $2.29 \mathrm{a}$ & $1.62 \mathrm{~b}$ \\
C6:0 & $0.08 \mathrm{~b}$ & $0.14 \mathrm{a}$ & 0.13 ÖD & 0.08 \\
C14:0 & 0.08 ÖD & 0.09 & 0.09 ÖD & 0.08 \\
C16:0 & 9.39 ÖD & 9.03 & $9.45 \mathrm{a}$ & $8.85 \mathrm{~b}$ \\
C16:1 & 0.18 ÖD & 0.18 & 0.19 ÖD & 0.18 \\
C17:0 & $0.05 \mathrm{a}$ & $0.04 \mathrm{~b}$ & 0.05 ÖD & 0.05 \\
C17:1 & 0.01 ÖD & 0.01 & $0.00 \mathrm{~b}$ & $0.02 \mathrm{a}$ \\
C18:0 & 3.63 ÖD & 3.45 & 3.67 ÖD & 3.36 \\
C18:1 cis (n-9) & 22.93 ÖD & 22.13 & $18.65 \mathrm{~b}$ & $28.35 \mathrm{a}$ \\
C18:2 trans (n-6) & 0.05 ÖD & 0.01 & 0.04 ÖD & 0.02 \\
C18:2 cis (n-6) & 61.24 ÖD & 61.72 & $64.61 \mathrm{a}$ & $56.77 \mathrm{~b}$ \\
C20:0 & 0.08 ÖD & 0.07 & 0.08 ÖD & 0.07 \\
C20:1 & 0.34 ÖD & 0.34 & $0.36 \mathrm{a}$ & $0.32 \mathrm{~b}$ \\
C20:2 & 0.00 ÖD & 0.00 & 0.00 ÖD & 0.00 \\
C21:0 & 0.02 ÖD & 0.01 & 0.02 ÖD & 0.01 \\
C20:5 (n-3) & $0.01 \mathrm{a}$ & $0.00 \mathrm{~b}$ & 0.00 ÖD & 0.00 \\
C22:6 (n-3) & $0.19 \mathrm{~b}$ & $0.39 \mathrm{a}$ & 0.34 ÖD & 0.21 \\
C24:1 & $0.01 \mathrm{~b}$ & $0.04 \mathrm{a}$ & 0.02 ÖD & 0.02 \\
\hline ISFA & 15.04 ÖD & 15.18 & $15.78 \mathrm{a}$ & $14.10 \mathrm{~b}$ \\
IMUFA & 23.47 ÖD & 22.70 & $19.22 \mathrm{~b}$ & $28.89 \mathrm{a}$ \\
I PUFA & 61.49 ÖD & 62.12 & $65.00 \mathrm{a}$ & $57.01 \mathrm{~b}$ \\
L UFA & 84.96 ÖD & 84.82 & $84.22 \mathrm{~b}$ & $85.90 \mathrm{a}$ \\
PUFA/SFA & 4.11 ÖD & 4.14 & 4.17 ÖD & 4.05 \\
\hline
\end{tabular}

*Her bir satırda farklı harflerle belirtilen ortalamalar istatistik olarak önemlidir $(\mathrm{P}<0.05)$.

Üzüm çeşitleri kabuk renklerine göre karşılaştırıldıklarında; bütirik, palmitik, heptadekanoik, oleik, linoleik ve eicosenoik asitlerin renkli ve beyaz çeşitlerde birbirinden farklı miktarlarda bulunduğu tespit edilmiştir. Diğer yağ asitlerinin ise çeşit rengine bağlı olarak değişim göstermediği belirlenmiştir. Linoleik, palmitik ve bütirik asit renkli üzüm çeşitlerinde, oleik asit ise 
beyaz üzüm çeşitlerinde daha yüksek miktarlarda saptanmıştır. Toplam doymamış yağ asidi miktarının beyaz çeşitlerde daha yüksek olduğu görülmektedir. Bununla birlikte bu farkın; tekli doymamış yağ asitlerinin beyaz çeşitlerde çok daha yüksek olmasından kaynaklandığı açığa çıkarılmıştır. Nitekim çoklu doymamış yağ asitlerinin toplamı; renkli çeşitlerde, beyaz çeşitlere oranla daha yüksek seyretmiştir. PUFA/SFA oranının ise çeşit rengine bağlı olarak değişmediği de belirlenmiştir.

\section{Sonuç ve Öneriler}

Çekirdeklerin pomolojik özelliklerinin anaççeşit interaksiyonuna göre değiştiği saptanmıştır. Bunlardan çekirdek eni ve boyu arasında pozitif yönde doğrusal bir ilişki olduğu belirlenmiştir. Aynı zamanda 1 kg'daki çekirdek sayısı ile 100 çekirdek ağırlığı arasında negatif yönde doğrusal bir ilişkinin varlığı da saptanmıştır. Çekirdeklerin kül miktarı hem anaç-çeşit interaksiyonlarına hem de anaçlara göre değişim göstermemiştir. Bağda kullanılan anacın aynı zamanda 100 çekirdek ağırlığı, çekirdek boyutları ve endosperm gelişimi üzerine etkileri önemsiz bulunmuştur. Çekirdek nemi ve kül miktarı hariç, incelenen tüm pomolojik özellikler üzerine çeşitlerin kabuk renginin etkisi olduğu belirlenmiştir.

Üzüm çekirdeklerinde yağ içeriğinin; çeşide göre değişim gösterdiği ancak bağda kullanılan anacın sabit yağ miktarını etkilemediği tespit edilmiştir. En yüksek sabit yağ oranı $1103 \mathrm{P}$ anacı üzerine aşılanmış Ata Sarısı üzüm çeşidinden elde edilmiştir. Aynı zamanda bu çeşit anaçlardan bağımsız bir değerlendirme yapıldığında da en yüksek yağ içeriğine sahip çeşit olarak belirlenmiştir. Elde edilen bulgular; yarı kurak iklim koşullarında üzüm çekirdeği yağı üretimi için bu çeşidin oldukça uygun olduğunu düşündürmektedir. Kabuk rengine göre bir değerlendirme yapıldığında ise beyaz üzüm çeşitlerinin, renklilere kıyasla çekirdeklerinde daha yüksek oranda sabit yağ içerdiği belirlenmiştir.

Incelenen çeşitlerin tamamında; her iki anaç üzerinde de en yüksek miktarda bulunan yağ asidinin linoleik asit olduğu, bunu sırasıyla oleik, palmitik, stearik ve bütirik asidin takip ettiği saptanmıştır. Linoleik asit içeriği bakımından 1103 P anacına aşılı Trakya İlkeren üzüm çeşidi öne çıkmıştır. Benzer bir şekilde anaçlardan bağımsız bir değerlendirme yapıldığında da, Trakya İlkeren üzüm çeşidi en yüksek linoleik asit içeriğine sahip çeşit olmuştur. Anaçların ise tek başına linoleik asit miktarına etki etmedikleri tespit edilmiştir.

Elde edilen bulgular genel olarak değerlendirildiğinde; bağda kullanılan anacın çekirdeklerin pomolojik özellikleri ve yağ asidi kompozisyonları üzerine etkilerinin sınırlı olduğu ancak çeşitlerin bu özellikler üzerinde mutlak bir etkilerinin olduğu söylenebilir. Ayrıca çeşitlerin kabuklarının renkliliklerine göre de söz konusu özelliklerin farklılık gösterdikleri araştırmamızda ortaya çıkarılmıştır.

\section{Teşekkür}

§: Bu çalışma M. İlhan ODABAŞıOĞLU'nun doktora tezinden türetilmiştir. Çalışmanın yapılmasına destek sağlayan HÜBAK (Proje no: 19022)'a araştırmacılar teşekkür eder.

\section{Kaynaklar}

Ağaoğlu, Y.S. 1999. Bilimsel ve Uygulamalı Bağcılık Cilt:1 Asma Biyolojisi. Kavaklıdere Eğitim Yayınları No:1, Ankara, 205s.

Ağaoğlu, Y.S. 2002. Bilimsel ve Uygulamalı Bağcılık Cilt:2 Asma Fizyolojisi-l. Kavaklıdere Eğitim Yayınları, No:5, Ankara, 445s.

Akın., A., Altındişli, A. 2010. Emir, Gök Üzüm ve Kara Dimrit Çeşitlerinin Çekirdek Yağlarının Yağ Asidi Kompozisyonu ve Fenolik Madde İçeriklerinin Belirlenmesi. Akademik Gıda, 8(6): 19-23.

Asadi, F., Shahriari, A., Chahardah-Cheric, M. 2010. Effect of long-term optional ingestion of canola oil, grape seed oil, corn oil and yoğurt butter on serum, muscle and liver cholesterol status in rats. Food and Chemical Toxicology, 48: 2454-2457.

Balu, M., Sangeetha, P., Murali, G., Panneerselvam, C. 2005. Age-related oxidative protein damages in central nervous system of rats: modulatory role of grape seed extract. Int. J. Devl. Neuroscience, 23: 501-507.

Balu, M., Sangeetha, P., Murali, G., Panneerselvam, C. 2006. Modulatory role of grape seed extract on age-related oxidative DNA damage in central nervous system of rats. Brain Research Bulletin, 68: 469-473.

Bashimov, G. 2017. Türkiye'de Üzüm Üretimi ve Ihracat Performansı. U. Ü. Ziraat Fakültesi Dergisi, 31(2): 57-68.

Bekar, T. 2016. Bağcılıkta Atık Teknolojisi. Iğdır Üni. Fen Bilimleri Enst. Der., 6(1): 17-24.

Beveridge, T.H.J., Girard, B., Kopp, T., Drover, J.C.G. 2005. Yield and Composition of Grape Seed Oils Extracted by Supercritical Carbon Dioxide Petroleum Ether: Varietal Effects. J. Agric. Food Chem., 53(5): 1799-1804.

Canbay, H.S., Bardakçı, B. 2011. Determination of Fatty Acid, C, H, N and Trace Element Composition in Grape Seed by GC/MS, FTIR, Elemental Analyzer and ICP/OES. SDU Journal of Science (E-Journal), 6(2): 140-148.

Crews, C., Hough, P., Godward, J., Brereton, P., Lees, M., Guiet, S., Winkelmann, W. 2006. Quantitation of the Main Constituents of 
Some Authentic Grape-Seed Oils of Different Origin. J. Agric. Food Chem., 54(17): 62616265.

Çelik, H., Kunter, B., Söylemezoğlu, G., Ergül, A., Çelik, H., Karataş, H., Özdemir, G., Atak, A. 2010. Bağcılığın Geliştirilmesi Yöntemleri ve Üretim Hedefleri. TMMOB Ziraat Mühendisleri Odası Ziraat Mühendisliği VII. Teknik Kongresi Bildiriler Kitabı-1. 11-15 Ocak, Ankara, s.493-513.

Çetin, A. 2010. Iyileştirir, Güzelleştirir Üzüm. Hayykitap, Genel Yayın No:117. Tabiattan Gelen Şifa Serisi No:2, İstanbul, 192s.

Demirtas, I., Pelvan, E., Özdemir, İ.S., Alasalvar, C., Ertas, E. 2013. Lipid characteristics and phenolics of native grape seed oils grown in Turkey. Eur. J. Lipid Sci. Technol., 115: 641647.

El-Shami, S.M., El-Mallah, M.H., Mohamed, S.S. 1992. Studies on the lipid constituents of grape seeds recovered from pomace resulting from White grape processing. Grasas y Aceites, 43(3): 157-160.

FAO, 2019. Food and Agriculture Organization of the United Nations Official Website. Grape production.

http://www.fao.org/faostat/en/\#data (Erişim tarihi: 25.09.2019).

Feng, Y., Liu, Y.M., Leblanc, M.H., Bhatt, A.J., Rhodes, P.G. 2007. Grape Seed Extract Given Three Hours After Injury Suppresses Lipid Peroxidation and Reduces Hypoxic-Ischemic Brain Injury in Neonatal Rats. Pediatric Research, 61(3): 295-300.

Fernandes, L., Casal, S., Cruz, R., Pereira, J.A., Ramalhosa, E. 2013. Seed oils of ten traditional Portuguese grape varieties with interesting chemical and antioxidant properties. Food Research International, 50: 161-166.

Garavaglia, J., Markoski, M.M., Oliveira, A., Marcadenti, A. 2016. Grape Seed Oil Compounds: Biological and Chemical Actions for Health. Nutrition and Metabolic Insights, 2016(9): 59-64.

Gök Tangolar, S., Özoğul, Y., Tangolar, S., Torun, A. 2009. Evaluation of fatty acid profiles and mineral content of grape seed oil of some grape genotypes. International Journal of Food Sciences and Nutrition, 60(1), 32-39.

Göktürk Baydar, N., Akkurt, M. 2001. Oil Content and Oil Quality Properties of Some Grape Seeds. Turk. J. Agric. For., 25: 163-168.

Göktürk Baydar, N., Özkan, G., Çetin, E.S. 2007. Characterization of grape seed and pomace oil extracts. Grasas y Aceities, 58(1): 29-33.
Hajati, H., Hassanabadi, A., Golian, A., NassiriMoghaddam, M., Nassiri, M.R. 2015. The Effect of Grape Seed Extract and Vitamin C Feed Supplementation on Some Blood Parameters and HSP70 Gene Expression of Broiler Chickens Suffering from Chronic Heat Stress. Italian Journal of Animal Science, 14(3): 3273-3281.

Kaçar, B. 1972. Bitki ve Toprağın Kimyasal Analizleri: II Bitki Analizleri. Ankara Üniversitesi Ziraat Fakültesi Yayın No:453. Ankara, 464s.

Kamal-Eldin, A., Andersson, R. 1997. A Multivariate Study of the Correlation Between Tocopherol Content and Fatty Acid Composition in Vegetable Oils. JAOCS, 74(4): 375-380.

Kamel, B.S., Dawson, H., Kakuda, Y. 1985. Characteristics and Composition of Melon and Grape Seed Oils and Cakes. JAOCS, 62(5): 881-883.

Kamiloğlu, Ö., Üstün, D. 2014. Bazı Şaraplık Üzüm Çeşitlerinin Hasat Sonrası Kalite Özellikleri. Türk Tarım ve Doğa Bilimleri Dergisi, 1(3): 361-368.

Kara, K., Kocaoğlu Güçlü, B., Baytok, E., Şentürk, M. 2016. Effects of grape pomace supplementation to laying hen diet on performance, egg quality, egg lipid peroxidation and some biochemical parameters. Journal of Applied Animal Research, 44(1): 303-310.

Lachman, J., Hejtmankova, A., Taborsky, J., Kotikova, Z., Pivec, V., Stralkova, R., Vollmannova, A., Bojnanska, T., Dedina, M. 2015. Evaluation of oil content and fatty acid composition in the seed of grapevine varieties. LWT-Food Science and Technology, 63: 620-625.

Mccarthy, M.G., Cirami, R.M., Furkaliev, D.G. 1997. Rootstock response of Shiraz (Vitis vinifera) grapevines to dry and drip-irrigated conditions. Australian Journal of Grape and Wine Research, 3: 95-98.

Matthaus, B. 2008. Virgin grape seed oil: Is it really a nutritional highlight? Eur. J. Lipid Sci., 110: 645-650.

Mironeasa, S., Leahu, A., Codina, G.G., Gabriel Stroe, S., Mironeasa, C. 2010. Grape Seed: physico-chemical, structural characteristics and oil content. Journal of Agroalimentary Processes and Technologies, 16(1): 1-6.

Ohnishi, M., Hirose, S., Kawaguchi, M., Ito, S., Fujino, Y. 1990. Chemical Composition of Lipids, Especially Triacylglycerol, in Grape Seeds. Agric. Biol. Chem., 54(4): 1035-1042.

OIV, 2019. International Organisation of Vine and Wine Official Website. Grape production. 
http://www.oiv.int/en/statistiques/recherc he (Erişim tarihi: 25.09.2019).

Oomah, B.D., Liang, J., Godfrey, D., Mazza, G. 1998. Microwave Heating of Grapeseed: Effect on Oil Quality. J. Agric. Food Chem., 46: 40174021.

Özkaya, A., Bakır, C., Şahin, Y., Uzun, K. 2014. Adıyaman'da Güneşte Kurutulan Üzüm ve İşlenmiş Kuru Üzümlerin Yağ Asitlerinin Karşılaştırmalı Değerlendirilmesi. Adıyaman Üniversitesi Fen Bilimleri Dergisi, 4(1): 18-26.

Pardo, J.E., Fernandes, E., Rubio, M., Alvarruiz, A., Alonso, G.L. 2009. Characterization of grape seed oil from different grape varieties (Vitis vinifera). Eur. J. Lipid Sci. Technol., 111: 188193.

Rababah, T.M., Ereifej, K.I., Al-Mahasneh, M.A., Ismaeal, K., Hidar, A.G., Yang, W. 2008. International Journal of Food Properties, 11: 472-479.

Rabak, F. 1921. Grape-Seed Oil. The Journal of Industrial and Engineering Chemistry, 13(10): 919-921.

Rubio, M., Alvarez-Orti, M., Alvarruiz, A., Fernandes, E., Pardo, J.E. 2009. Characterization of Oil Obtained from Grape Seeds Collected during Berry Development. Journal of Agricultural and Food Chemistry, 57(7): 2812-2815.

Sabir, A., Unver, A., Kara, Z. 2012. The fatty acid and tocopherol constituents of the seed oil extracted from 21 grape varieties (Vitis ssp.). J. Sci. Food Agric., 92: 1982-1987.

Sağdıçoğlu, H. 2018. Investigation of Different Quality Parameters of Some Grapes in Sanliurfa Conditions. MSc, Harran University, Sanliurfa, Turkey.

Santos, L.P., Morais, D.R., Souza, N.E., Cottica, S.M., Boroski, M., Visentainer, J.V. 2011. Food Research International, 44: 1414-1418.

Serra, I., Strever, A., Myburgh, P.A., Deloire, A. 2014. The interaction between rootstocks and cultivars (Vitis vinifera L.) to enhance drought tolerance in grapevine. Australian Journal of Grape and Wine Research, 20: 114.

Singh, C.K., Liu, X., Ahmad, N. 2015. Resveratrol, in its natural combination in whole grape, for health promotion and disease management. Annals of the New York Academy of Sciences, 1348(2015): 150-160.

Sivaprakasapillaia, B., Edirisingheb, I., Randolphc, J., Steinbergc, F., Kappagodaa, T. 2009. Effect of grape seed extract on blood pressure in subjects with the metabolic syndrome. Metabolism Clinical and Experimental, 58: 1743-1746.
Slover, H.T., Lanza, E. 1979. Quantitative Analysis of Food Fatty Acids by Capillary Gas Chromatography. JAOCS, 56: 933-943.

Stefanoudaki, E., Kotsifaki, F., Koutsaftakis, A. 1999. Classification of Virgin Olive Oils of the Two Major Cretan Cultivars Based on Their Fatty Acid Composition. JAOCS, 76(5): 623-626.

Triushenski, J.T., Boesenberg, J., Kohler, C.C. 2009. Influence of Grow-Out Feed Fatty Acid Composition on Finishing Success in Nile Tilapia. North American Journal of Aquaculture, 71: 242-251.

TÜiK, 2019. Türkiye İstatistik Kurumu Resmi Web sitesi. Bitkisel Ürün Denge Tabloları. https://biruni.tuik.gov.tr/medas/?kn=104\&l ocale=tr (Erişim tarihi: 25.09.2019).

Uslu, A., Dardeniz, A. 2009. Bazı Üzüm Çeşitlerinin Çekirdeklerindeki Yağ Asitleri Bileşenlerinin Belirlenmesi. Selçuk Tarım ve Gıda Bilimleri Dergisi, 23(48): 13-19.

Yi, C., Shi, J., Kramer, J., Xue, S., Jiang, Y., Zhang, M., Ma, Y., Pohorly, J. 2009. Fatty acid composition and phenolic antioxidants of winemaking pomace powder. Food Chemistry, 114: 570-576.

Yoo, J.Y., Shin, D.H., Min, B.Y. 1984. Composition of Grape Seed Oil. Korean J. Food Sci. Technol., 16(3): 257-260. 